\title{
The "Green" Term and Accounting Education
}

Fibriyani Nur Khairin ${ }^{1}$, Eko Ganis Sukoharsono ${ }^{2}$, Roekhudin ${ }^{3}$, Bambang Hariadi $^{4}$

Accounting Department University of Mulawarman, Samarinda, Indonesia ${ }^{1}$, Accounting Department University of Brawijaya, Malang, Indonesia ${ }^{1,2,3,4}$

\begin{abstract}
Purpose - This paper aims to uncover the meaning of "green" through the point of view of accounting educators.

Design/methodology/approach - Ecophenomenology is used as a methodology to uncover the meaning of "green" by involving three professors from several universities in Indonesia who focus on sustainability and green accounting as informants.

Findings - This research shows that accounting educators provide a deeper meaning related to green, which in addition to considering the triple bottom line (3P) concept also includes values/beliefs as spiritual elements in it. "Green" is specifically interpreted as a process of harmony in life.

Practical Implications - Finding of this research contributes to construct green accounting education's form that not only focuses on the concept of business with $3 \mathrm{P}$ aspects but there is a spiritual aspectalization, so that accountants resulting from such education have a holistic view of their environment.

Originality/value - Terminology in the field of green accounting is experiencing rapid development both in terms of meaning and new terms that emerge. Not much research has paid attention to the definition and meaning of the term yet, especially the term "green" itself. Whereas, the term and it's meaning might impact to the development of green accounting education.
\end{abstract}

Vol. 28, No. 2 August 2020

(C) Centre for Indonesian Accounting and Management Research Postgraduate Program, Brawijaya University 
Keywords - Accounting, Ecophenomenology, Education, Sustainability, Terminology

Paper Type - Research Paper

\section{INTRODUCTION}

Along with the presence of a rapidly growing environmental awareness which is also followed by the need to take into account environmental welfare. The company and the business world both understand and formulate steps to promote green and green behavior for the present and the future. Among other steps being taken, in this case a new branch of accounting called "environmental accounting or green accounting," on another occasion it is also called resource accounting or integrated accounting. These terms are used interchangeably with considered similar meanings.

Accounting that takes into account social and/or environmental factors has shown developments in recent years in accounting history. In line with its development several terminology and definitions have also been present that refer to this new accounting branch (Hernádi, 2012; Seto-Pamies \& Papaoikonomou, 2015). The availability of various sources of information increases the spread of terms and definitions, as used by various authors and organizations (Glavi \& Lukman, 2018). Several common terminologies used in scientific papers, monographs, textbooks, company annual reports, the use of government policies, and the media include environmental accounting, environmental and social accounting, triple bottom line accounting, green accounting, environmental accounting disclosure, social and environmental reporting; social responsibility accounting; sustainability accounting (McHugh, 2007); and triple bottom line reporting (Raar, 2002).

Studying this terminology problem, Glavi \& Lukman (2018) revealed as a result of the many new terms popping up, or existing ones Vol. 28, No. 2 August 2020 (C) Centre for Indonesian Accounting and Management Research Postgraduate Program, Brawijaya University 
expanded in the field of sustainability and green accounting, but a lack of critical attention was paid to their semantic definitions and meanings. The many definitions can also cause confusion about their use, because the meanings of some terms are often similar, or only slightly different from one another (Glavi \& Lukman, 2018). The terminology itself can be interpreted as an explanation of the actual purpose of a term. While the word "term" refers to a combination of words used to indicate the meaning of concepts, processes, circumstances or special characteristics in a particular field.

A terminology has various dimensions that make it up. If it relies on ecophenomenology, the experience and awareness of the actors should also be considered as dimensions involved in the formation of a terminology. Defining terms is a separate but important issue in this discussion. The terminology in accounting (especially green accounting) is something that deserves attention. This is due to the lack of "mention" uniformity of the terms in the accounting field. The absence of similarity in this term leads to the variety of meanings given to the terms formed, so that accounting education that absorbs the meanings of these various terminologies is also carried out based on various definitions and objectives.

Not much research has highlighted that using different terminology to designate the same object will lead to different results. Then this paper aims to uncover the meaning of "green" through the point of view of accounting educators. This study contributed to understanding of using spesific terminology, will also bring differences in determining the direction of accounting education. Afterwards, the meaning of the terminology which constructs by those educators can be used as a basis for the development of green accounting education. In line with this, the ecophenomenological view that is used to highlight the meaning of terminology stating that the mind or duality of the world is ultimately more responsible for our environmental crisis than greed, ignorance, and apathy, especially industrial capitalism and free market

Vol. 28, No. 2 August 2020

(C) Centre for Indonesian Accounting and Management Research Postgraduate Program, Brawijaya University 
ideology that is considered a strength. And phenomenology are considered capable and strength to really express the intrinsic environmental values, without falling back into some of the myths ethical given (Thomson, 2004).

\section{LITERATURE}

\subsection{Terminology and Terms}

Each discipline has terms that contain special meaning in it. Then, the science of terms or more clearly is the science of explaining the meaning of several terms known as terminology. Glavi \& Lukman (2018) stated that terminology represents an integrated framework for all related terms and serves as a basis for communication within a particular scientific field. So that terminology becomes important in studying a field of science because it can give us an understanding of the definitions or meanings that are specific to the terms contained in that field of science. Thus, the terminology is not only limited to linguistics study (Faber \& Rodriguez, 2012). There are often several terms that seem to have a common meaning and are used interchangeably or there is no agreement on meaning of a definition.

There are also several terms that seem to have a similar meaning and used interchangeably, or even there is no specific agreement of meaning and definition for a certain term. Furthermore, this is where this research positions itself. In the field of sustainability and green accounting, those phenomena also exist. In policy, media or scientific research there are terms that are assumed to have similar meanings and this can sometimes confuse other researchers and readers, such as green accounting, environmental accounting, social and evironmental accounting and sustainability accounting. Those term sometime used interchangeably, but its actually have different meaning. Then it also

Vol. 28, No. 2 August 2020

(C) Centre for Indonesian Accounting and Management Research

Postgraduate Program, Brawijaya University 
needs to be understand what is "green" in perspective of actor in accounting field, including educators.

\subsection{Accounting Education}

The term 'sustainability' was firstly used in German forestry circles by Hans Carl von Carlowitz in his book Sylvicultura Oeconomica in 1713. Carlowitz suggested nachhaltende nutzung (utilization) of forest resources, which implied maintaining a balance between old trees which were cut (harvest) and ensure that there are enough saplings to replace them (André Feil \& Schreiber, 2017; Pisani, 2006). Afterward, in line with the increasing demands for economic growth, development and the lifestyles of industrial countries which threaten the ecological balance, economic stability and security of the planet, around 1960 and 1970 a debate emerged which later inspired the creation of the concept of sustainable development (André Feil \& Schreiber, 2017). The goal of sustainable development is in order to balance the limits of growth with development needs.

The increasing attention to sustainability has an impact on the paradigm shift in the business world and business course, including accounting. Then comes the green accounting education to accommodate the values of sustainability in accounting field. Nowadays the role of education is getting bigger, because it is considered to be able to offer new solutions to the problems of global community (Shobha \& Kala, 2015). Howieson (2003) stated that the purpose of green counting education is faced with challenges to consider also the changes in environment, society and technology that occur in order to be integrated into education. This condition causes accounting education to become increasingly complex to be managed because the business environment continues to develop (Jones \& Abraham, 2008). The practice of education will definitely be more dynamic and challenging to meet the complex changes in various environmental variables in the future, such as

Vol. 28, No. 2 August 2020

(C) Centre for Indonesian Accounting and Management Research Postgraduate Program, Brawijaya University 
technology, economics, ecology, social and rapidly changing environments.

\section{METHODOLOGY}

This study is qualitative in interpretive paradigm research with ecophenomenology approach. Interpretive paradigm is a perspective that relies on the goal of understanding and explaining the social world from the perspective of the actors involved in it. This paradigm is suitable to be used in this study to achieve the objectives expected to be answered from this research. In line with this paradigm and to answer research questions, an ecophenomenological approach is applied to understand the phenomenon of green accounting from the perspective of accounting educators. In ecophenomenology, humans and nature are in the ontological realm that are not mutually isolated and in a similar context. Thus, there is no object or subject between humans and nature, this is called equilibrium (Dewi, 2015). Human connectedness with the ecosystem in a review of the ecophenomenology of proving the existence of a reciprocal relationship, which in essence are not mutually exclusive. But in ecophenomenology, actually want to emphasize that though different nature, man is the subject involved (Wood, 2003).

The informants involved in this research are three accounting professors (in this research they called as AL, AU, and AD) from several universities in Indonesia who's concerned (experts) in the field of green accounting to express their views related to the meaning of "green" and green accounting education. Currently the informants are focusing their various works towards environmental and social awareness or sustainability issues in the field of accounting education. This study explores data from informants through interviews with certain topics. Then method to analyzed the data used modified model of temathic analysis by Clarke \& Braun (2013). Stage of analysis was divided into several steps: (1) familiarising with the data; (2) generating initial codes; (3) searching for themes; (4) reviewing themes; (5) defining and naming for themes; (6) producing the report.

Vol. 28, No. 2 August 2020

(C) Centre for Indonesian Accounting and Management Research

Postgraduate Program, Brawijaya University 


\section{RESULT AND DISCUSSION}

Awareness of the role of accountants in supporting the realization of SDG leads to what kind of view of accounting education that can later contribute to that goal. The view of the contributions made is inseparable from the background of the informants in the world of education they are in. This also influences the meaning of the term "agreed" to be used. Ecophenonemology comes from a combination of two terms, ecology and phenomenology and is categorized as a theory in an ethical context that is carried out through radical understanding while encouraging ontological (Dewi, 2015: 3). As also stated by Wood (2003) ecophenomenology to reveal the experiences of the actors related to the transformation of their paradigms and mindset in terms of their awareness of environmental concerns.

\section{1 "Green" as Harmony}

Awareness of the role of accountants in supporting the realization of SDG leads to what kind of view of accounting education that can later contribute to that goal. The view of the contributions made is inseparable from the background of the informants in the world of education they are in. $\mathrm{AL}$ as one of the research informants, often expressed the word "green" during the discusssion process. The term refers to the specific meaning given.

"Green" is considered not only limited to contexts related to the environment, but goes beyond that if interpreted from the point of view of the philosophy of color and spirituality. According to the AL, "green" means as a process of harmonization and contains spiritual values in it. This is stated in one of the following interview passages:

"In philosophy of color, if I'm not mistaken, there are two meanings, green is talking about the harmony of life ... green is

Vol. 28, No. 2 August 2020

(C) Centre for Indonesian Accounting and Management Research Postgraduate Program, Brawijaya University 
interpreted as the harmony of life between one another. God said that in the perspective of Islam, green is the harmony of life. The second is the body-prana-heaven. So that person if he enters heaven goes to shades of green, among other things, after death if the person lives well then he enters into that delicious heavenly environment which is green. So I think the Islamic perspective that green is the harmony of life that in the end after this prana life all of us are expected to return to the creator and enter heaven. Then if there are three aspects in Christianity [green: teachings], basically green is full of hope, full of optimism and then there is harmony with one anothers. Then in Hindu and Buddha, I think it would be the same, also something like the others religion explain. Even though it's different, but they are the same. "

Then this harmony which then led the AL to a [new] sight of what he referred to as "green accounting." The main motivation behind "green accounting" was the concern that human activity would create significant environmental damage that was not captured by accounting conventional. This condition is expressed by the $\mathrm{AL}$ as an impact of the ego and pragmatic attitude of accounting. Basically, conventional accounting practices mainly focus on profitability as the only indicator of business performance and market value of its shares (Tinker, 2014). Concentration on capitalistic modes of production, so that social and environmental responsibility is often sacrificed. This is also supported by the emphasis on an academic curriculum that implements profit as the main determinant of business success (Mcphail, 2001; Tinker, 2014). For most people, the term "business" will be synonymous with "profit" (Hinton \& Maclurcan, 2017).

In line with Tinker (1985) AL also criticizes the focus on earnings as the only business performance criterion, which causes accounting to overlook significant social problems. This error is also aimed at generally accepted accounting principles because it does not adequately cover a large number of social and environmental problems, and causes corporate scandals. It is said that conventional accounting practices cannot balance

Vol. 28, No. 2 August 2020

(C) Centre for Indonesian Accounting and Management Research

Postgraduate Program, Brawijaya University 
the opposite objectives between profitability and social responsibility. When synergy does not occur, then in conventional accounting harmony will not exist.

\section{2 "Green" as Interrelatedness}

The following presentation is a representation of the results of interviews with the AU and AD. Slightly different from the views of the previous informants, the results of the interviews of these two informants are dominated by the term "sustainability" that refer the "green." Sustainability is a very complex idea and is understood and defined, in many different ways (R. Gray \& Bebbington, 2000). At its simplest, this definition can be broken down into several components: current needs, future needs; environmental stewardship; and social justice (R. Gray \& Collison, 2002).

As Redclift (1993a) states that "sustainability is a close relationship between economic, environmental and social." Similarly, the AU stated:

"If we pay attention in the context of terminology, initially people actually only know CSR, only the problem of each party has its own emphasis on developing. For environmentalists, they tend to focus on the environment. then CSR is finally broken down, social and environmental aspects. There is also a sense of euphoria in the use of the term, so people start using "green," there is green business, there is green management. But the meaning of it all is how the corporation can run its business not only financial problems but also social and environmental issues. Actually, everything empties there. Then the ends in the term sustainability include everything."

From an ecophenomenological point of view, the inseparability between nature and humans can also be described through the term sustainability. Specifically, sustainability accounting is interpreted by $\mathrm{AD}$ as environmentally friendly and socially accountable accounting. On that occasion he also explained the meaning of sustainability through a view

Vol. 28, No. 2 August 2020

(C) Centre for Indonesian Accounting and Management Research Postgraduate Program, Brawijaya University 
of ecosystems, how the interrelatedness (interrelatedness) of everything on earth. An explanation is accompanied by a detailed description of how human behavior is based on the desire to meet their needs and instead exploits nature, leading to environmental damage. When one aspect of "damaged" in the ecosystem chain, it will also be damaged all aspects that exist in this. This view of self-awareness as an inseparable subject from nature is the emphasis of ecophenomenology.

Sustainability accounting based on awareness of the position of interrelation (interrelatedness) is then emphasized by the $\mathrm{AD}$, which is considered to embody the character of accountants who are proenvironment if brought into accounting education. The focus of the mindset by $\mathrm{AD}$ and $\mathrm{AU}$ is on management accounting because it is assumed that sustainability accounting is a policy that is taken and carried out by an entity / company and is an internal issue within the organization itself. So, it would be inappropriate if viewed through the perspective of financial accounting where the objectives and outputs produced are also different.

In the business world, current management needs focus on both cost and environmental accounting. Although financial accounting is also important, but often in this field dwell on standards and financial statements that are beyond the reach of management in determining its policies. This view is inseparable from the expectations of the role of accountants in supporting SDGs. The role of accountants is no longer only played as a party that produces financial and sustainability reports, but creators, enablers, preserves, and reporters on the values of sustainability in an organization.

Accountants can play an important role in realizing sustainability if viewed through these roles. The concept of interconnectedness in this role also appears clear, when accountants fail in the stage of creating organizational values that lead to pro-environment behavior, the resulting report will certainly not support sustainability. Awareness that is formed through a holistic view that what one party does within the scope of an ecosystem will have an impact on the other party and this cycle will

Vol. 28, No. 2 August 2020

(C) Centre for Indonesian Accounting and Management Research

Postgraduate Program, Brawijaya University 
continue, can be a rationale for determining policies and actions to be taken.

\subsection{Green Accounting Education}

Conventional accounting that is developing at this time is said to be in the realm of anthropocentrism (Nandan \& Lodhia, 2004; Ng, Leung, \& Lo, 2017). Conventional accounting which is the most common form of accounting does not consider many factors such as environmental expenditure or expenditure incurred to prevent pollution for example. No study of cause and effect relationships can cause environmental incidents for businesses or organizations. Conventional accounting does not study or measure the exhaustion of environmental resources or consider environmental degradation. Through this explanation of the anthropocentric position, it can be understood that there is a disharmony between the science of accounting (and accountants) with nature.

So how can the accounting profession play a role in sustainability if the world is interpreted to be in the anthropocentric sphere? The expected role of the profession is then passed down also to accounting education which is the printer of these professionals. Shifting anthropocentrism as a tendency of accountants' mindset has become a major project in education (accounting) (Postma, 2006; Saylan \& Blumstein, 2011) According to Gray, (2019) in this case the fundamental question is related to what we (as teachers and / or students) believe are educational goals (in accounting) and the extent to which education must carefully consider the implications of very different conceptions of what sustainability really means. So that the meaning of "green" that was sparked by the informants and discussed earlier can be used as a foundation in building the concept of accounting education.

When the business process is likened to the "kill the golden goose" action, the accountant's role in sustainability becomes even greater. Although initially there was a debate about the various roles of accountants in sustainability, but in its development it was stated that accountants contribute in the "accountability" aspect. The role of professional accountants is to fulfill the public interest regarding the

Vol. 28, No. 2 August 2020

(C) Centre for Indonesian Accounting and Management Research Postgraduate Program, Brawijaya University 
responsibilities of economic actors to shareholders / associates, employees, customers, suppliers, countries, banks, investors, etc. (Makarenko \& Plastun, 2017; Sorina-Geanina, Adriana, \& Ana-Maria, 2018). Other literature reveals that the accounting profession has various roles to play in helping to choose the right mechanism and make it work efficiently so that the desires of individuals, society and government are realized. In other words, professional accountants have the information, values, reports and mechanisms needed to move the business towards practices that support sustainability (Sorina-Geanina et al., 2018).

Although the various roles of accountants in sustainability discussed are inseparable from sustainable development based on the concept of "Triple Bottom Line," Krempl, (2014) revealed that it would not be complete without the presence of a pillar of spirituality. It added that there were various opinions about sustainable development and changes in interdisciplinary disciplines, the views found identified gaps in the sustainable development model as agents of change that referred to missing elements as spiritual emptiness, lack of ethical foundation priorities, and to the so-called with a higher level of thought (Krempl, 2014; Sachs, 2012).

In line with the AL's view that this gap is caused partly by the absence of a spiritual dimension that underlies practices in green accounting (or sustainability). It was revealed that:

"Without spirituality, practices such as CSR, for example, will only be a new way to simply make a good image of the company, or avoid taxes, or as a way to wash hands of the environmental damage done. That's it, ma'am, if the one who runs it doesn't have the right foundation. "

The continual change of terminology and reinterpretation of meaning carried out in terms of developing global policies, then having a new initial effect without being followed by intentions and actions needed to be expressed also as a trigger for the failure (Krempl, 2014). So that the meaning of terminology that agreed to be used becomes an important thing. The informants' view of terminology that tends to be used in the

Vol. 28, No. 2 August 2020

(C) Centre for Indonesian Accounting and Management Research

Postgraduate Program, Brawijaya University 
field of green accounting based on ecophenomenology which has a spiritual nuance in it becomes more appropriate to be integrated as a basis for the development of the concept of sustainable development and green accounting education.

\section{CONCLUSSION}

This study has found the meaning of "harmony" and "interrelatedness" between planet, profit, amd people; over the "green" term. Although the dimensions of spirituality expressed are diverse, they can form a holistic concept of sustainable development. Furthermore, by relying on this holistic view that will be able to bring changes also in the form of sustainbility accounting education. The meaning of harmony that is based on the nature of love and interrelatedness that strives to instill a sense of reluctance to do damage to the slightest nature, is expected to underlie a deep accounting education and can produce accountants with pro-environmental behavior.

\section{REFERENCES}

André Feil, A., \& Schreiber, D. (2017). Sustainability and sustainable development: unraveling overlays and scope of their meanings. Cadernos EBAPE.BR, 14(3), 667-681. https://doi.org/10.1590/1679-395157473

Clarke, V., \& Braun, V. (2013). Teaching thematic analysis: Overcoming challenges and developing strategies for effective learning. The Psychologist, 26(2), 120-133.

Dewi, S. (2015). Ekofenomenologi: Mengurai Disekuilibrium Relasi Manusia dengan Alam. Tangerang Selatan: Marjin Kiri.

Faber, P., \& Rodriguez, C. I. L. (2012). Terminology and specialized languange. In P. Faber (Ed.), A Cognitive Linguistics view of terminology and specialized language (hal. 9-32). Berlin, Germany: Walter de Gruyter GmbH \& Co.

Glavi, P., \& Lukman, R. (2018). Review of sustainability terms and their

Vol. 28, No. 2 August 2020

(c) Centre for Indonesian Accounting and Management Research Postgraduate Program, Brawijaya University 
definitions. Journal of Cle, 15(February), 1875-1885. https://doi.org/10.1016/j.jclepro.2006.12.006

Gray, R. (2019). Sustainability Accounting and Education: Conflicts and Possibilities. In K. Amaeshi, J. N. Munthuri, \& C. Ogbechie (Ed.), Incorporating Sustainability in Management Education: An Interdisciplinary Approach (hal. 33-54). Switzerland: Palgrave Macmillan.

Hernádi, B. H. (2012). Green Accounting for Corporate Sustainability. Club of Economics in Miskolc, 8(2), 23-30.

Hinton, J., \& Maclurcan, D. (2017). A not-for-profit world beyond capitalism and economic growth ?, 17(1), 147-166.

Howieson, B. (2003). Accounting practice in the new millennium: Is accounting education ready to meet the challenge? British Accounting Review (Vol. 35). https://doi.org/10.1016/S08908389(03)00004-0

Jones, G., \& Abraham, A. (2008). Preparing accountants for today's global business environment: The role of Emotional Intelligence in accounting education. In 11th Annual International Conference of the American Society of Business and Behavioral Sciences (hal. 2527). Honolulu, Hawaii.

Krempl, S. (2014). Is spirituality the essence of sustainability. In J. Lunn \& S. Bizjak (Ed.), The truth is out there (hal. 169-181). Perth, Western Australia: Black Swan Press.

Makarenko, I., \& Plastun, A. (2017). The role of accounting in sustainable development. Accounting and Financial Control, 1(2), 4-12. https://doi.org/10.21511/afc.01(2).2017.01

McHugh, J. (2007, Desember). Accountants "Have Key Role in Sustainability"'. Public Finance.

Mcphail, K. (2001). The dialectic of accounting education: From role identity to ego identity. Critical Perspectives on Accounting, 12(4), 471-499. https://doi.org/10.1006/cpac.2000.0444

Nandan, K., \& Lodhia, K. (2004). Current Environmental Accounting Problematic: A Shift from Anthropocentrism to Ecocentrism. Accountancy Business and the Public Interest, 3(1), 1-31.

Ng, A. W., Leung, T. C. H., \& Lo, J. M. K. (2017). Developing

Vol. 28, No. 2 August 2020

(C) Centre for Indonesian Accounting and Management Research

Postgraduate Program, Brawijaya University 
Sustainability Competence for Future Professional Accountants: The Integrative Role of an Undergraduate Program. In Handbook of Theory and Practice and Sustainable Development in Higher Education (Vol. 1, hal. 119-136). Switzerland: Springer.

Pisani, J. A. Du. (2006). Sustainable development - historical roots of the concept. Environmental Sciences, 3(2), 83-96. https://doi.org/10.1080/15693430600688831

Postma, D. W. (2006). Why care for nature? In search of an ethical framework for environmental responsibility and education. (M. Korthals \& P. B. Thompson, Ed.). Netherlands: Springer.

Raar, J. (2002). Environmental initiatives: Towards triple-bottom line reporting. Corporate Communications: An International Journal, 7(3), 169-183. https://doi.org/10.1108/13563280210436781

Sachs, J. D. (2012). From millennium development goals to sustainable development goals. The Lancet, 379(9832), 2206-2211. https://doi.org/10.1016/S0140-6736(12)60685-0

Saylan, C., \& Blumstein, D. T. (2011). The failure of environmental education (and how we can fix it). California: University of California Press.

Seto-Pamies, D., \& Papaoikonomou, E. (2015). A Multi-level Perspective for the Integration of Ethics, Corporate Social Responsibility and Sustainability ( ECSRS ) in Management Education. Journal of Business Ethics, 136(3), 1-16. https://doi.org/10.1007/s10551-014-2535-7

Shobha, S., \& Kala, N. (2015). Value Education towards Empowerment of Youth-A Holistic Approach. Procedia - Social and Behavioral Sciences, 172, 192-199. https://doi.org/10.1016/j.sbspro.2015.01.354

Sorina-Geanina, S., Adriana, P. (Horaicu), \& Ana-Maria, C. (Andrei). (2018). The role of the accounting profession in achieving the objectives of sustainable development. Economy Series, (3), 117122.

Thomson, I. (2004). Ontology and Ethics at the Intersection of Phenomenology and Environmental Philosophy. Inquiry, 47, 380412. https://doi.org/10.1080/00201740410004197

Vol. 28, No. 2 August 2020 (C) Centre for Indonesian Accounting and Management Research Postgraduate Program, Brawijaya University 
Tinker, T. (1985). Paper prophets: A social critique of accounting. New York: Praeger.

Tinker, T. (2014). Love Canal and the return of paper prophets : a social critique of mainstream accounting. African Journal Accounting, Auditing and Finance, 3(2), 143-148.

Wood, D. (2003). What is Eco-Phenomenology. In C. S. Brown \& T. Toadvine (Ed.), Eco-Phenomenology: Back to earth itself (hal. 211234). New York: Sunny Press. 